\title{
STAND-UP COMEDY: \\ THE RELATION BETWEEN LANGUAGE AND CULTURE
}

\author{
Sri Winarsih \\ sriwinarsih@unmus.ac.id \\ English Literature Department \\ Universitas Musamus
}

\begin{abstract}
Stand-up comedy is a kind of entertainment which presents the art and speech competence. As a single performer on the stage without any supporting properties and partners, a comic is permitted to express any utterances and strived for making audiences laugh. So, language aspect is the most important element of this art in the form of utterances. Based on the theory that language both expresses and embodies cultural identity, concerning stand-up comedy a question then emerged; How are language and culture related by comics' utterances? This study aims to describe the content and the way of the utterances expressed by comics in stand-up comedy; to reveal how language and culture are closely related. The data were collected from videos of Indonesian Stand-Up Comedy season 4 of the three winner comic performances. Through collecting, analyzing, presenting and interpreting the data as the steps of qualitative method employed, the finding shows that content of the utterances expressed by the comics represent their own culture included ethnicity and community which are related to the problem dealing with their social life. While, the way they express the utterances shows that there are striking differences among the three comics in uttering the sounds, words, sentences and gimmick. The content differences identify their cultural and social background. Stand-up comedy art reveals how the language closely related to the culture.
\end{abstract}

Keywords: comic, culture, language, language identity, stand-up comedy

\section{INTRODUCTION}

Nowdays, there are many talent shows in television programs. One of them is stand-up comedy show. For some people in Indonesia, stand-up comedy may be recognized as a new entertainment which was pioneered by a male artist, RadityaDika, but the information given by Sjobohm (2008, p. 4) that its concept is basically rooted in the very old art of comedy and it is recognized wellborn in United State and then was slowly spreading to other countries.

Mintz (1985, p. 71) stated a statement dealing with stand-up comedy as an encounter between a single, standing performer behaving comically and or/saying funny things directly 
to an audience, unsupported by very much in the way of costume, prop, setting, or dramatic vehicle. It means that stand-up comedy can be defined as a comedy which is performed by a single performer who stands on the stage, acting and saying funnily directly to audiences without any striking attributes such as costumes, properties, designed settings, and dramatic tools, it is just telling a joke.

It is supported by Sjobohm (2008, p. 5) who described stand-up comedy as a very simple performance art in term of production. It is compared by other comedy performances which almost always supported by many kinds of sparsely used properties, costumes, settings supporting the theme of the show. Comics' goal is to attract the interest of the audience throughout the performance. So it can be said that in stand-up comedy, utterance is the most important aspect that not emphasized in any other arts. Utterance is the only what comic delivers to audiences. Technically, the audiences do not hold any turn for speaking. They only get entertained by comics' utterances.

Related to what delivered to audiences, utterances are used in the activity in stand-up comedy and they refer to the content.Filani (2015, pp. 53-57)stated that stand-up comedy activity determines how comics will construct and present their jokes and the audiences will interpret. The product of the activity is the content of utterances.

While, Mintz (1985, p. 75)stated "On the role of stand-up comedians, refers to them as comic spoke persons, mediators, articulators of our culture, social commentators, and our contemporary anthropologists". The statement shows that a comic can be as that based on what the content they uttered. The statement is in line with Kim and Sherman (2007, p. 2) who viewed that people commonly express their beliefs through media. Here, stand-up comedy potentially becomes a media to express self's belief, experiences, and values through these actions and words.By doing it people reveal those attributes. Through these selfexpressive acts, individuals make their private thought, and feelings concrete, tangible, and socially recognizable, and having freedom to speak one's mind symbolizes one's ultimate freedom to be oneself.

Related to Mintz and Kim and Sherman's statement above, comics may become as particular agent through words and actions as their self-expression is supported by two statements of Kramsch (1998, p. 3), that language expresses cultural reality and language embodies cultural reality. There are two points of those statements. The first is that language expresses cultural reality, and the second is language embodies cultural reality. A man can be articulator for certain culture because he articulates element of the culture trough language. The elements can addresses to experiences whether those derive from social, political, 
educational and cultural experiences. So, the language becomes the vehicle to express, as Leech (2006, p. 101), and Kiesler and Sakamura (1996, p. 351)support it by stating that individuals might feel more committed when their thoughts are expressed through words and behavior in because what is expressed as belief and thought implicate central aspects of who they are. This is emphasizes internal attributes in defining the self.

Kramsch (1998, p. 65) added that language of social group and group identity is naturally connected which can be identified by the accent, vocabulary, and discourse patterns. Speakers both identify and are identified as members of certain community. Accent is the way of people sound when they speak. It in line with Biner $(1999$, p. 2), "The other kind of accent is simply the way a group of people speak their native language. This is determined by where they live and what social groups they belong to. In reality everybody has an accent."

As known that comics in stand-up comedy comes from many different places, even different country. In Indonesia for instance, stand-up comedy lovers are increased over the times because people love laughing. Everybody is permitted to perform on its stage. The comics come from many places in Indonesia. So, it can be imagined the comedy will present various kinds of expressions. Widiastuti $(2013$, p. 8) in her study said "the condition of Indonesia as an archipelagic country with various ethnic groups which has the diversity of thinking, art, religion, science, languages and traditions of local cultures with unique and different characteristics." So, it will be very interesting and meaningful to analyze stand-up comedy from the aspect of language and culture expressed by the comics because culture differs in their views on self-expression, individuals from different cultures may view and practice self-expression differently as well.

As a comedy show, stand-up comedy is different with most comedy shows in television which commonly performed by a group of comedians on the stage at the same time. Stand-up comedy is performed only by a person on the stage in about seven or ten minutes. A stand-up comedian is commonly called a comic. As a comic, he is strived for making audiences laugh as often as possible over the performance using his words, no partner to have back and forth jokes. So, verbal competence and other aspects of speech is very important element in this art.

A study had been done by Katayama (2009) concerning stand-up comedy. Katayama compared two cross-culture comics, between American and Japan by analyzing the discourse of their live stand-up comedy performances. He stated in his study that there is different 
pervasive pattern of the two comics in their performance, and he suggested for farther study to contribute to examine culture in close relation to language.

While in Indonesia, Setyaningrum (2013) employed a study dealing with culture and language which the data collected from SUCI 3 show. In her study, she focused on analyzing ethnic stereotype expressed in stand-up comedy which represented by three ethnicities in Indonesia; Bataknese, Maduranese, and East Indonesian. She stated in the result of her study that ethnic background of the comics influences their jokes.

One of television channels which organizes stand-up comedy talent show is Kompas TV. The show namely SUCI which stands for Stand-Up Comedy Indonesia has organized for five seasons, and it has just about been announced for the following season six audition. In each seasons, the comics came from various places around Indonesia such as Jakarta, Bandung, Surabaya, Makassar, even East Indonesia. It is automatically fancy of different kinds of speech styles and stories, and interesting indeed.

Deriving from the result of both studies above, the question is emerged; To what extent the ethnic background influences the jokes, the content of or the way expressing the jokes? Hence, this study aims to describe the content and the way of the utterances expressed by comics in stand-up comedy; to reveal how language and culture are closely related.

\section{METHOD}

This study was employed by qualitative method which consists of three steps namely collecting, analyzing, presenting and interpreting the data. The data were collected from videos of Indonesian Stand-Up Comedy season 4 (SUCI 4) performances at Kompas TV downloaded from Youtube.com, and then transcribed and loosely translated. The sample is only collected from three comics with two performances, so there are six transcriptions as the data being analyzed.

\section{FINDING AND DISCUSSION}

This section discusses the content of the utterances which indicates the culture and the way of the utterances preformed which shows the language of the comics. As previously mentioned, there are three comics representing the various performances in SUCI 4 show. They were the winner of the show; David was the winner, Abdur as first runner up, and Dzawin as second runner up. 
The data is in the form of excerpts of transcription collected from show 13 which themed 'fashion' and show 14 which allowing comics to bring a media as the theme. The translation is written under each utterance.

\subsection{Content of the Utterances}

\section{First Comic: David}

David, a comic comes from Jakarta which is known as a native Betawi. He was the winner of SUCI 4 show.Before joining SUCI 4, he had experienced in sometypes of random job. (Pamungkas, 2014.Tabloidbintang.com).

\section{Excerpt 1}

"Betawi mah mohon maaf bukan kita kagak mau dandan. Laki bini di rumah sering berantem gara-gara dandan. Coba, lakinya tadinya kagak rapi, rapi sedikit bininya nyap-nyap, kampung mane yang baru ada jande?

("Sorry, Betawi doesn't want to make over. Husband and wife at home are often fighting because of making over. Let see, the husband previously was not tidy, then he is tidy the wife grumbled. Which village is there a new widow?")

"Empok, gue bilangin amalu ye, dulu ni mall tanah engkong buyut gue, kalo engkong buyut gue kagak jual kebos lu, lu kagak bakal kerja dimari, ngerti lu?"

("Hi you, I tell you, in the past this mall was my great grandpa's, if he didn't sell to your boss, you would never work here, understand?")

David talks about Betawi people. He illustrates a husband and wife in Betawi household story. When the husband suddenly makes over which is previously never, then his wife complains much because she suspiciously thinks that must be another woman makes him act differently. David intends to show that Betawi people is simple where fashion for Betawi people is not important aspect in their life. It is supported by his following story about mall in Jakarta is only for high class people, not included Betawi people, meant that Betawi people as low class in their own local land which is marginalized by the buildings of the city.

There are two points as the content showed in Expert 1 uttered by David; Betawi people are simple and they are as the native people of Jakarta who are marginalized.

\section{Excerpt 2}

"Yaelah.. bang_Markun pakai sandal jepit bang maman naek teronton, Assalamualaikum aye dapit pria idaman para penonton."

("Markun wears sandal, Maman drives truck. Assalamualaikum I am dapit, the audiences' idol man.") 
"Jaman dulu ada warkop yang judul lagunya betawi ini lagunya, masih inget nggak om Indro? Ini lagunya om (the song was played, "malam minggu di betawi semua warga begadang, kecuali nyai gua."

("In the past, there was Warkop with the song entitled Betawiinilagunya, do you remember, omIndro? This is the song om (the song played), "Saturday night in Betawi, all people are awake all night, but my grandma.")

David brings Betawi song as the media to fulfill the theme determined by the management of the show. And then, he explores the traditional arts of Betawi people those are Pantun (verses) and the song that tells story all about Betawi created by a Betawi group singer namely Warkop. He again links the story about lost of Betawi land as the impact of the building.

There are two points of the content of this excerpt; traditional art of Betawi people represented by verse and song, and again, they are marginalized in their own local land.

\section{Second Comic: Abdur}

Abdur is a comic originally comes from a small village namely Lamakera of Larantuka region in the East Nusa Tenggara who was studying in a university in Malang.(Pangerang, 2015.KOMPAS.com)

\section{Excerpt 3}

"Tidak mungkin. Dua minggu yang lalu kami kepante ancol itu teman-teman, aduh mama sayang e. saya baru pertama kali lihat itu pante ancol itu air laut nya itu hitam gelap tidak bisa liat apa-apa. Itu macam oli mesin kita kasih pasir itu.

("Impossible. Two weeks ago, we went to Ancol guys, oh gosh. It was the first time I saw Ancol beach is dark. It is like machine oil added by sand.")

"Kain yang saya pake ini, (touching the kain) ini salah satu motif, hanya salah satu dari seribu motif kainadat yang ada di NTT. Seribu teman-teman."

("The cloth I wear this (touching the cloth) is one of thousand motifs, only one of thousand motifs of traditional clothes in NTT. Thousands guys.)

Abdur firstly talks about Ancol beach in Jakarta after he had an experience visiting it. The description of black and dirty he made addressed to Ancol beach means the comparison he creates to potential nature belongs to NTT, his hometown. He also tends to say that although NTT is left in the building aspects but it has many beautiful natures. Then, he shows one of thousands traditional cloth motif belongs to NTT as the meaning of NTT people still hold traditional cloth dealing with fashion. 
There are two points of the content in excerpt 3; Potential nature of NTT as the East of Indonesia and the people in NTT hold and keep the tradition as the culture represented by the traditional cloth.

\section{Excerpt 4}

"Sebenarnya malam hari ini itu saya kepengen sekali berada di panggung ini kemudian bawa sasando, alat music asli NTT, begitu_Cuman apa daya saya tidak bisa main sasando.

("Honestly, tonight I want to be on this stage and bring Sasando, traditional musical instrument from NTT. But poorly I cannot play it.")

The media actually chosen by Abdur, it is Sasando, traditional music instrument of NTT. The fact is that he cannot play Sasando, because he has never been learned to play it. It describes the generation of NTT need to learn Sasando to keep the culture alive, so that Sasando as one of traditional culture does not end in the museum as history. And then he tells that men in the East identically known as drunken men.

There are three points of the content of excerpt above; Sasando is a traditional music instrument belongs to NTT, the lost of generation for keeping the culture, and drunken habit in the East people.

\section{Third Comic: Dzawin}

Dzawin was the second runner up of SUCI 4 show. He comes from Bogor and had studied in Islamic College in Banten. He is an English literature student in certain university. (Putri, 2014LPMInstitut.com)

\section{Excerpt 5}

“Gua dulu' pertam aawal-awal gua lulus pesantren, gue ni jujur gua nggak ngerti art idari fashion pakean yang gaul itu yang up todate gua nggak nggak ngerti kek gimana. Karena menurut gua pakaian itu fungsinya hanya sekedar untuk menutupi auurat. Ya terserah mau bahannya dari katun kek jeans kek lateks, spandex, poster baleho, banner ya sama aja gitu."

( 'In First time I graduated from Islamic college, honestly I didn't know the meaning of fashion, the fashionable clothes as up-to date I didn't know. Because for me, clothing functions as covering genitals. Whatever made from what materials, it can be cotton, jeans, latex, spandex, poster, billboard, banner, the same.")

Dzawin telling his experience as a Islamic college student. For him, previously he thinks that the important of fashion is covering the genitals area as ordered in Islam regulation. It shows the influence of his study in college. And then he describes the importance of fashion that representing attitude. He complains about any actions even brutal by namingon religion as the reason to do that. 
The points of the content in this excerpt are two; the importance of fashion is based on religion regulation, and the position of being tolerant people to others.

\section{Excerpt 6}

"Dan gue ini enem taun di pesantren, enem taun di salah satu pesantren modern di daerah banten, dan gua selama enam taun itu terbiasa dengan cewek-cewek wanita-wanita yang berjilbab dan itu sampai sekarang masih tertanam dalam diri gua makanya nanti kalo misalnya gua punya istri gua pengen istri gua itu berjilbab, makanya mbak Feni kalo udah siap dipake yajilbabnya. " (looking at Feny Rose)

("I had been six years in Islamic college, six years in one of modern Islamic college in Banten, and during the period I'd been common with girls using veil and it is buried in me, so if I have a wife I hope the one who wears veil, hence dear Feni if you are ready, wear your veil please.")

Dzawin shows his preference about the girl who wears veil to who do not. He hopes that the girl he loves will wears it. And then, he uses a sarong as a media to give tutorial about wearing sarong as what he learnt during in the college. He also reminds that showing off is forbidden as in the religion often reminded.

There are two points of the content from the last excerpt; religion regulation of wearing veil for women and forbiddance of being show off, and tradition of wearing sarong in the college for men.

From those points of the content created by comics from different background show that the content uttered by them express their cultural reality they have experienced. David, a Betawi man who had experienced in passing difficulty of life tends to talk about his protest on the buildings on his local land.Abdur who comes from the East represents the condition in his local land and introduces the cultural potency belongs to the East of Indonesia. While Dzawin, eventhough he comes from Bogor, he tends to share experiences of being Islamic college students and include religion material in his utterances.

The contents of the utterances show the cultural background whether from ethnic, regional, and social group background. All are covered as the term of culture reality.

\subsection{The Way of the Utterances Produced}

This section discusses the way of comics produced the utterance analyzed from the tendency of making different verbal speech features such as sound, word, sentence, gimmick. 
Table 1: Different Utterances Produced by the Comics

\begin{tabular}{|c|c|c|c|}
\hline $\begin{array}{c}\text { Different } \\
\text { utterances }\end{array}$ & David & Abdur & Dzawin \\
\hline \multirow[b]{2}{*}{ Sound } & Mane, jande, ye & Pake & - \\
\hline & Kite & $\begin{array}{l}\text { sékali, mabok }, \\
\text { tanggalam, tajatoh, }\end{array}$ & - \\
\hline \multirow[t]{2}{*}{ Word } & $\begin{array}{l}\text { mah, lakibini, } \\
\text { engkongbuyut, } \\
\text { dimari, nyap-nyap, } \\
\text { mpok, kagak, ama, lu }\end{array}$ & $\begin{array}{l}\text { teman-teman, men, } \\
\text { macam, bapa }\end{array}$ & - \\
\hline & nyok, nyai, ngapa & beta, trada, lai, sagu & Item, nggak \\
\hline Sentence & - & Sayapunyabapa & - \\
\hline Gimmick & Yaelah & aduh mama sayange & $E$ aing $a$. \\
\hline
\end{tabular}

*the cells show the excerpt sequence

The table shows how comics produced the utterances in different ways whether the sound, word, sentence, and gimmick.

David represents Indonesian language used in Betawi people. The sounds /e/ in the words mane, jande, ye, and kite are as the changes of /a/ of the words mana, janda, yaand kita. While Abdur does the some in uttering /e/ in the word pake as the change of the word pakai. Indonesian people commonly say pake’ with /ǽ/ but Abdur says pake with /e/. Abdur also says sekali with /e/ when common Indonesian people say sekali with /ə/, also Mabok as the word mabuk in common, tanggalam as tenggelam, and tajatoh for terjatuh. He tends to change vowel ' $a$ ' with ' $\mathrm{e}$ ' and vice versa. Abdur represents the East Indonesian in producing the sound in utterances. While Dzawin uses the proper sound as common Indonesian people uttered.

The striking difference is seen in the utterance of saying 'No'; David says kagak, Abdur says tida, and Dzawin says nggak, also in the utterance of calling their sibling like 'father, grandmother, or grandparent.' David calls his grandmother by Nyai', grandfather by Engkong, while Abdur calls his father by bapa eliminating $/ \mathrm{k} /$. Saying the first singular pronoun is also different. David and Dzawin say the same, gue or sometimes gua, while Abdur says saya sometimes beta.

And there is interesting way in Abdur's utterance when say sayapunyabapa which is meant 'my father', but for proper Indonesian language sayapunyabapak means 'I have father'. This kind of style would be very interesting to study further. 
There are also gimmick they uttered as their characteristic expression; David with yaelah, Abdur with aduh mama sayang $e$, and Dzawin with $e$ aing a. those three gimmicks have been their characteristics which represent their identities.

From the three comics' utterances, it clearly shows that their way to express the utterances influenced by their ethnicity which is part of culture. Dzawin may not often show the language of native Bogor people and rarely produces different utterances because of his educational background as an English literature student which automatically learn more about literacy. But it is absolutely needed farther study to deal with its glance statement. However, it does not change the point underlined from whole result that language embodies in the cultural reality.

\section{CONCLUSION}

Stand-up comedy is a kind of entertainment which presents the art and speech competence. Producing utterances as a single performer on the stage without any supporting property and partners is what a comic have to do. A comic is invited to perform their utterances in his own style. That rule leads a tendency for the comic to explore, to share, to express the utterances based on his experiences, his feelings, his preferences, and his hopes.

Expressing experience must be influenced by the comic's background. The background of family, identity, social group, and community, all of them are referred to what is called culture. Therefore, stand-up comedy show can be functioned as cultural show because whether consciously or unconsciously realized, the show presents the various speech styles and informs the cultures around people's life. For instance, Betawi people produce utterances in Betawi style telling about Betawi's culture, and so does the East Indonesian people. Their utterances tells their condition in the east which may be not known by people in Java. And social group and education are also named as cultural reality. The comics use language to express their cultural reality and the language itself embodies within the culture.

\section{REFERENCES}

Biner, Betty (Ed.). (1999). Why do some people have an accent? Washington: Linguistic Society of America.

Filani, Ibukun. (2015). Discourse types in stand-up comedy performances: an example of Nigerian stand-up comedy. European Journal of Humour Research, 3, 41-60. 
Katayama, Hanae. (2009). A Cross-Cultural Analysis of Humor in Stand-Up Comedy in the United States and Japan. The Journal of Linguistic and Intercultural Education, 2, 125 142 .

Kiesler, C. A., \&Sakamura, J. (1996).A test of a model of commitment. Journal of Personality and Social Psychology, 3, 349-353.

Kim, Heejung S., \& Sherman, David K. (2007). "Express Yoursef": Culture and the Effect of Self-Expression on Choice. In press, Journal of Personality and Social Psychology, 1, $1-14$.

Kramsch, Claire. (1998). Language and Culture. New York: Oxford University Express.

Leech, G. (2006). A Glossary of English Grammar. Edinburgh: Edinburgh University.

Mintz, L. E. (1985). Stand-up comedy as social and cultural mediation. American Quarternarly, 37, 71-80.

Pamungkas, YohanesAdi. (2014). Juara SUCI 4 IniPernahJadiTukangOjek. Retrieved 8th January, 2016, from http:/www.tabloidbintang.com/articles/berita/sosok/12268-davidnurbianto-juara-suci-4-ini-pernah-jadi-tukang-ojek

Pangerang, MutyyaKeteng. (2015). Abdur SUCI 4 InginSegeraMenyandangGelar Master. Retrieved 8th January, 2016, from http://entertainment.kompas.com/read/2015/06/22/191013010/Abdur.SUCI.4.Ingin.Seg era.Menyandang.Gelar.Master

Putri, Gita NawangsariEstika. (2014). DzawinBerpesanDalamGuyonan. Retrieved 8th January, 2016, from http://www.lpminstitut.com/2014/05/dzawin-berpesan-dalamguyonan.html

Setyaningrum, Nina. (2013). Ethnic Stereotypes in stand-up comedy. Paper presented at the The 5th ICSSIS International conference on Indonesian studies: "Ethnicity and Globalization", Yogyakarta.

Sjobohm, Juan M. (2008). Stand-up comedy around the world: americanisation and the role of globalised media. Malmo University, Sweden.

Widiastuti.(2013). Analisis SWOT KeragamanBudaya Indonesia.JurnalIlmiah WIDYA, 1, 814.

\section{Youtube Videos}

AbdurSasando (SUCI 4 Show 14). (2014). retrived from hhtps://youtu.be/61zQJ_Q5hzY on 15th February 2014

AbdurTempatKejadian Fashion TKP (SUCI 4 Show 13) (2014). retrived from http://youtu.be/sk4dvbUEjw0 on 15th February 2014 
David BetawiIniLagunya (SUCI 4 Show 14). (2014). retrived from https://youtu.be/iUOg9DSJfjs on 15th February 2014

David TukangOjegBanyak Gaya (SUCI 4 Show 13. (2014). retrived from https://youtu.be/kTAxbmX1RFY on 15th February 2014

DzawinButa Fashion (SUCI 4 Show 13). (2014). retrived from https://youtu,be/5u-RzE0a8gS on 15th February 2014

DzawinIklanMusiman (SUCI 4 Show 14). (2014). retrived from https://youtu.be/pKBA2WmhTvc on 15th February 2014 